\title{
Breastfeeding rate and speech-language therapy in the Kangaroo Method
}

\author{
Caroline Stefani Dias Basso ${ }^{1}$ \\ https://orcid.org/0000-0002-9951-6829 \\ Marta Alves da Silva Arroyo ${ }^{1}$ \\ https://orcid.org/0000-0002-5862-3396 \\ Maria Amélia Branco Fecuri Saes ${ }^{1}$ \\ https://orcid.org/0000-0002-3866-2048 \\ Lilian Beani ${ }^{1}$ \\ https://orcid.org/0000-0003-1620-7447 \\ Aline Barbosa Maia ${ }^{1}$ \\ https://orcid.org/0000-0002-9396-3599 \\ Luciano Garcia Lourenção² \\ https://orcid.org/0000-0002-1240-4702
}

Faculdade de Medicina de São José do Rio Preto - FAMERP - São José do Rio Preto, São Paulo, Brasil.

2 Universidade Federal do Rio Grande FURG, Rio Grande, Rio Grande do Sul, Brasil.

Project carried out at the Hospital da Criança e Maternidade, Faculdade de Medicina de São José do Rio Preto FAMERP, São José do Rio Preto, São Paulo, Brasil.

Conflict of interests: Nonexistent

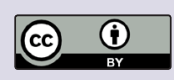

Received on: July 25, 2019

Accepted on: November 14, 2019

Corresponding address:

Marta Alves da Silva Arroyo

Faculdade de Medicina de São José do Rio Preto - FAMERP

Avenida Brigadeiro Faria Lima, $n^{0} 5416$,

Vila São Pedro

CEP: 15090-000 - São José do Rio Preto,

São Paulo, Brasil

E-mail: martaalvesarroyo@gmail.com

\section{ABSTRACT}

Purpose: to verify the hospital discharge rate in breastfeeding and speech-language practice during implementation of the kangaroo method in a tertiary-level teaching hospital.

Methods: a retrospective and documentary study, whose data were collected from electronic medical records of all preterm and/or low birth weight newborns, born at or admitted to a teaching hospital, from August 2016 to August 2017, and who had received care by the speech-language team. Data were collected regarding sample characterization (gender, Apgar, gestational age, birth weight, and orotracheal intubation time); speech-language therapy time; description of the procedures used, such as weight to start breastfeeding, empty breast technique, translactation, and feeding method at the time of speech-language therapy and hospital discharge. Appropriate statistical tests were applied, adopting a significance level lower than $0.05 \%$.

Results: there was a higher rate of breastfeeding in moderately preterm infants, born in a gestational age of 30 to 34 weeks, and in low birth weight newborns.

Conclusion: breastfeeding was the prevalent feeding method for newborns. The results show that the speech-language stimulation of newborns was adapted from the conventional model to that proposed by the Kangaroo Method, corroborating with humanized care guidelines.

Descriptors: Newborn, Preterm; Kangaroo Method; Breastfeeding; Speech, Language and Hearing Sciences; Child Health 


\section{INTRODUCTION}

Breastfeeding offers many benefits for the baby and the mother'. It favors the development of the newborn's (NB) stomatognathic functions, as the process of sucking the breast generates an adequate stimulus for the orofacial muscles ${ }^{2,3}$.

Adequate breastfeeding demands the mother's dedication, NB's stimulation, proper guidance and follow-up, and family support, in addition to the health professionals' competence and knowledge on preterm infants' anatomophysiology. If there is specialized help, guidance, stimulation, support and follow-up, the preterm infant will be able to breastfeed from their own mother before hospital discharge ${ }^{4}$.

The kangaroo method $(\mathrm{KM})$ is a neonatal assistance approach aimed at humanized care, proposing a set of actions which changed the assistance patterns to preterm (PTNB) and/or low-birth-weight newborns $(L B W)^{5}$, so as to favor mother-child bonding, breastfeeding and temperature control by including the mother in the care. One of the proposals in this method is the baby's positioning on the mother's chest, thus promoting skin-to-skin contact, allowing for the baby's better thermal stability and contributing to early discharge, which decreases hospital infection rates and increases the quality of care, lowering the costs for the health system ${ }^{6}$.

According to the World Health Organization (WHO), PTNB is every live NB whose gestational age (GA) at birth was of up to 37 complete weeks; and, LBW is every NB whose weight is equal or inferior to $2.5 \mathrm{~kg}$. Based on the GA, late preterm NB is the one born between 34 weeks and 36 weeks and six days; moderately preterm is the one born between 30 and 34 weeks of GA; and, extremely preterm is the one born with less than 30 gestational weeks. The NB classification regarding weight also defines as very low birth weight NB (VLBW) those whose weight is lower than $1.5 \mathrm{~kg}$; extremely low birth weight NB (ELBW) those whose weight is lower than $1.0 \mathrm{~kg}$; and, micro-preemie NB those whose weight is lower than 800 grams $^{7}$.

The speech-language therapist must integrate the minimum high-risk NB care team, according to the kangaroo method, and be inserted in the integral and humanized care units to attend NBs in serious or potentially serious condition at the Sistema Único de Saúde - SUS (Brazil's publicly funded health care system) $)^{5-8}$. The work of this professional aims to safely and efficiently establish an adequate functioning of the stomatognathic system, the maturity and coordination of the sucking, breathing and swallowing mechanisms, and the transition to oral feeding, as well as promote breastfeeding ${ }^{6}$.

Studies state that the PTNB need to use alternative feeding routes until physiological aptitude takes place so that sucking-swallowing-breathing functions are coordinated, at around 32 to 34 weeks of gestational age, and weight equal or superior to $1.5 \mathrm{~kg}^{9,10}$. This is the practice in many hospitals in the country, and, in the hospital where this study was conducted, weight equal or superior to $1,500 \mathrm{~g}$ and gestational age between 32 and 34 weeks are considered conditions for oral feeding to be introduced. Nevertheless, the kangaroo method promotes early introduction to breastfeeding, as compared to other care methodologies ${ }^{11}$, regardless of weight and gestational age, proposing interventions such as the empty breast technique, translactation, kangaroo position, and the use of a cup as a complement for oral diet.

In this context, the implementation of the kangaroo method at the research hospital required modifications in the practice of various teams, including the speechlanguage one.

Currently, the agreement between the traditional and the kangaroo method of speech-language therapy is that the newborn must be clinically stable and must coordinate the functions of sucking, swallowing and breathing. The kangaroo methodology and the speech-language practice with neonates also agree on promoting early breastfeeding.

Hence, this study aimed at verifying the breastfeeding rate upon discharge from the hospital, and describing the speech-language practice in the period of implementation of the kangaroo method in a tertiarylevel teaching hospital.

\section{METHODS}

This study was approved by the Research Ethics Committee of the Faculdade de Medicina de São José do Rio Preto - FAMERP, SP, Brazil, with Consubstantiated Evaluation Report number 2.294.080. The signing of the Informed Consent Form was not requested, as the data were collected from the medical records.

This study was based on a retrospective, documentary, quantitative approach, conducted by means of data collection from medical records of preterm and/or low-birth-weight newborns, whose birth or hospital admission took place between August 2016 and August 2017, at the Neonatal Intensive Care Unit 
(NICU), the Neonatal Intermediate Care Unit (NIMCU) and the Kangaroo Method Neonatal Intermediate Care Unit (KANIMCU) of the Hospital da Criança e Maternidade de São José do Rio Preto, SP, Brazil, who were followed up by the speech-language team. At the time the study was being conducted, the kangaroo method was in its implementation process.

The PTNB and/or LBW inpatients of the abovementioned units who received speech-language treatment during stay were included in the study. Those who presented syndromes and congenital malformations were excluded.

The data were obtained from the patients' electronic medical records, considering the following variables: sample characterization (gender, APGAR, gestational age (GA), birth weight (BW), orotracheal intubation time), speech-language care time, description of procedures used, such as weight to begin breastfeeding, empty breast technique, translactation, and feeding method at the moment of both speech-language and hospital discharge.

Appropriate statistical tests were applied, adopting a significance level lower than $0.05 \%$.

\section{RESULTS}

Two hundred and fifty-nine newborns met the inclusion criteria, There was a prevalence of SUS admissions $(83.0 \%)$ and male patients (51.7\%); $73.4 \%$ and $96.2 \%$ of the NBs presented Apgar score higher than or equal to seven, at the first and fifth minute, respectively. Of the NBs, $22.8 \%$ were extremely preterm, $46.3 \%$ were moderately preterm, $29.7 \%$ late preterm, and $1.2 \%$ full-term NBs.
Regarding birth weight, $5.0 \%$ were classified as extremely low birth weight, $23.2 \%$ very low birth weight, $55.6 \%$ low birth weight, $7.3 \%$ adequate birth weight, and $0.4 \%$ as excessive birth weight. There was a need of orotracheal intubation in $33.6 \%$ of these patients for an average time of five days, being it for one day at the least and 96 days at the most. Furthermore, 56.3\% of the NBs remained intubated up until seven days of life, and $43.7 \%$ remained intubated for a time longer than seven days.

The full-term NBs were included in the study for being born with low birth weight (below 2,500 g). The NBs with adequate and excessive birth weight were born with gestational age inferior to 37 weeks and were also included in the study.

The average time from birth to the first speechlanguage therapy was of six days. At the moment of speech-language assessment, $90.8 \%$ of the NBs were being fed via alternative feeding route; $0.8 \%$ of these had enteral feeding, and $90.0 \%$, gastric feeding tube, of which $67.6 \%$ had orogastric tube.

The average bedside speech-language intervention time was of 14 days, with at least one day and at most 130 days of stimulation; $86.1 \%$ of the NBs were discharged with low weight.

As shown in Table $1,86.5 \%$ of the NBs were breastfeeding when discharged, $48.3 \%$ of which were exclusively breastfeeding, and $38.2 \%$ with mixed breastfeeding; $75.6 \%$ were placed by their mother's breast in their first week of life; $25.9 \%$ had their first contact with their mother's breast when weighing $1,500 \mathrm{~g}$ or less; $7.7 \%$ were submitted to the empty breast technique; and, $16.6 \%$ went through the relactation/translactation technique. 
Table 1. Speech-language practice in the humanized proposals of the kangaroo method and feeding method at speech-language discharge

\begin{tabular}{lcc}
\hline Variable & $\mathbf{N}$ & $\%$ \\
\hline Period between speech-language assessment and first time placed by mother's breast & \\
On the same day & 83 & $32 \%$ \\
1 to 3 days & 72 & $27.8 \%$ \\
4 to 7 days & 41 & $15.8 \%$ \\
8 to 10 days & 13 & $5 \%$ \\
11 to 15 days & 18 & $6.9 \%$ \\
16 to 20 days & 08 & $3.1 \%$ \\
Over 20 days & 11 & $4.2 \%$ \\
Was not placed by the mother's breast & 12 & $4.6 \%$ \\
\hline Weight when 1st placed by mother's breast & & \\
Up until 1,500 g & 67 & $25.9 \%$ \\
Over $1,500 \mathrm{~g}$ & 178 & $68.7 \%$ \\
Was not placed by the mother's breast & 12 & $4.6 \%$ \\
Not recorded & 02 & $0.8 \%$ \\
\hline Relactation/Translactation & & $16.6 \%$ \\
Was submitted to the relactation/translactation technique & 43 & $83.4 \%$ \\
Was not submitted to the relactation/translactation technique & 216 & $7.7 \%$ \\
\hline Empty breast technique (Nonnutritive sucking) & & $92.3 \%$ \\
Was submitted to the empty breast technique & 20 & \\
Was not submitted to the empty breast technique & 239 & $48.3 \%$ \\
\hline Feeding method at speech-language discharge & & $7.7 \%$ \\
Exclusive breastfeeding & 125 & $0.8 \%$ \\
breastfeeding associated with cup complementation & 20 & $29.7 \%$ \\
breastfeeding associated with syringe complementation & 02 & $0.4 \%$ \\
breastfeeding associated with baby bottle complementation & 77 & 34 \\
Baby bottle & 01 & \\
Not recorded & & \\
\hline
\end{tabular}

Concerning the feeding method at the moment of speech-language discharge (Table 2), exclusively breastfeeding was the most frequent $(47.9 \%)$, especially in moderately PTNB (22.4\%), with low birth weight (32.8\%), and not having needed to be intubated (38.2\%). Among the NBs who needed to be intubated, breastfeeding with complementary baby bottle was the most frequent (6.9\%). 
Table 2. Feeding route at the moment of speech-language discharge, according to gestational age, birth weight and time of intubation

\begin{tabular}{|c|c|c|c|c|c|c|c|c|}
\hline & \multicolumn{7}{|c|}{ Feeding at speech-language discharge } & \multirow[b]{2}{*}{ P-value* } \\
\hline & Baby bottle & $\begin{array}{c}\text { Exclusive } \\
\text { breastfeeding }\end{array}$ & $\begin{array}{l}\text { Breastfeeding } \\
\text { and cup }\end{array}$ & $\begin{array}{l}\text { Breastfeeding } \\
\text { and baby bottle }\end{array}$ & $\begin{array}{l}\text { Breastfeeding } \\
\text { and syringe }\end{array}$ & Not mentioned & Total & \\
\hline \multicolumn{9}{|l|}{ Gestational age } \\
\hline Extremely preterm & $13(5.0)$ & $14(5.4)$ & $5(1.9)$ & $26(10.0)$ & $1(0.4)$ & - & $59(22.8)$ & \multirow{5}{*}{0.006} \\
\hline Moderately preterm & $16(6.2)$ & $58(22.4)$ & $7(2.7)$ & 37 (14.3) & $1(0.4)$ & $1(0.4)$ & $120(46.3)$ & \\
\hline Late preterm & $5(1.9)$ & $50(19.3)$ & $7(2.7)$ & $14(5.4)$ & - & $1(0.4)$ & $77(29.7)$ & \\
\hline Full-term & - & $2(0.8)$ & $1(0.4)$ & - & - & - & 3 (1.2) & \\
\hline Total & $34(13.1)$ & $124(47.9)$ & $20(7.7)$ & $77(29.7)$ & $2(0.8)$ & $2(0.8)$ & $259(100.0)$ & \\
\hline \multicolumn{9}{|l|}{ Birth weight } \\
\hline Micro-preemie & $7(2.7)$ & $4(1.5)$ & $1(0.4)$ & $10(3.9)$ & - & - & $22(8.5)$ & \multirow{7}{*}{0.005} \\
\hline $\begin{array}{l}\text { Extremely low } \\
\text { weight }\end{array}$ & $2(0.8)$ & $2(0.8)$ & $2(0.8)$ & $7(2.7)$ & - & - & $13(5.0)$ & \\
\hline Very low weight & $12(4.6)$ & $18(6.9)$ & $4(1.5)$ & $25(9.7)$ & $1(0.4)$ & - & 60 (23.2) & \\
\hline Low weight & $11(4.2)$ & $85(32.8)$ & $13(5.0)$ & $32(12.4)$ & $1(0.4)$ & $2(0.8)$ & $144(55.6)$ & \\
\hline Adequate weight & $2(0.8)$ & $14(5.4)$ & - & $3(1.2)$ & - & - & $19(7.3)$ & \\
\hline Excessive weight & - & $1(0.4)$ & - & - & - & - & $1(0.4)$ & \\
\hline Total & $34(13.1)$ & $124(47.9)$ & $20(7.7)$ & $77(29.7)$ & $2(0.8)$ & $2(0.8)$ & $259(100.0)$ & \\
\hline \multicolumn{9}{|l|}{ Days of intubation } \\
\hline Did not intubate & $16(6.2)$ & $99(38.2)$ & $14(5.4)$ & $41(15.8)$ & $1(0.4)$ & $1(0.4)$ & $172(66.4)$ & \multirow{4}{*}{0.003} \\
\hline $\begin{array}{l}\text { From one to seven } \\
\text { days }\end{array}$ & $10(3.9)$ & $16(6.2)$ & $4(1.5)$ & $18(6.9)$ & & $1(0.4)$ & $49(18.9)$ & \\
\hline Over seven days & $8(3.1)$ & $9(3.5)$ & $2(0.8)$ & $18(6.9)$ & $1(0.4)$ & - & $38(14.7)$ & \\
\hline Total & $34(13.1)$ & $124(47.9)$ & $20(7.7)$ & $77(29.7)$ & $2(0.8)$ & $2(0.8)$ & $259(100.0)$ & \\
\hline
\end{tabular}

* Chi-squared test.

Of the 133 NBs who needed their diet to be complemented at the moment of speech-language discharge, $76(57.1 \%)$ had it complemented with baby bottle. The main justification for such need was the low production of breast milk (71.4\%), as shown in Table 3.

Table 3. Justification of the need to complement the newborns' diet

\begin{tabular}{|c|c|c|c|c|c|c|c|}
\hline & \multicolumn{6}{|c|}{ Feeding at the speech-language discharge } & \multirow[b]{2}{*}{ P-value* } \\
\hline & Baby bottle & $\begin{array}{c}\text { Breastfeeding } \\
\text { and cup } \\
\text { complementation }\end{array}$ & $\begin{array}{c}\text { Breastfeeding } \\
\text { and baby bottle } \\
\text { complementation }\end{array}$ & $\begin{array}{l}\text { Breastfeeding } \\
\text { and syringe } \\
\text { complementation }\end{array}$ & Not mentioned & Total & \\
\hline \multicolumn{8}{|c|}{ Justification of the need to complement } \\
\hline Little breast milk production & $10(7.5)$ & $17(12.8)$ & $66(49.6)$ & $2(1.5)$ & - & $95(71.4)$ & \\
\hline $\begin{array}{l}\text { Asked by mother/did not } \\
\text { want to breastfeed }\end{array}$ & $14(10.5)$ & - & $9(6.8)$ & - & - & $23(17.3)$ & \\
\hline $\begin{array}{l}\text { Complement of milked } \\
\text { breast milk }\end{array}$ & - & $2(1.5)$ & - & - & - & $2(1.5)$ & \\
\hline Mother contraindication & $9(6.8)$ & - & - & - & - & $9(6.8)$ & $<0.001$ \\
\hline Sleepy newborn & - & - & $1(0.8)$ & - & - & $1(0.8)$ & \\
\hline Newborn's little weight gain & - & $1(0.8)$ & - & - & - & $1(0.8)$ & \\
\hline Inefficient sucking & $1(0.8)$ & - & - & - & - & $1(0.8)$ & \\
\hline Not mentioned & - & - & - & - & $1(0.8)$ & $1(0.8)$ & \\
\hline Total & $34(25.6)$ & $20(15.0)$ & $76(57.1)$ & $2(1.5)$ & $1(0.8)$ & $133(100.0)$ & \\
\hline
\end{tabular}

* Chi-squared test. 
Sixty-nine mothers (26.6\%) made use of silicone nipple shields, the main reason for $56(81.1 \%)$ of them being the presence of flat nipples. At the moment of hospital discharge, $91.3 \%$ of these mothers were breastfeeding, $37.7 \%$ being exclusively on breast milk.

Table 4. Relation between the reason to use silicone nipple shield and the newborn's feeding method at speech-language discharge

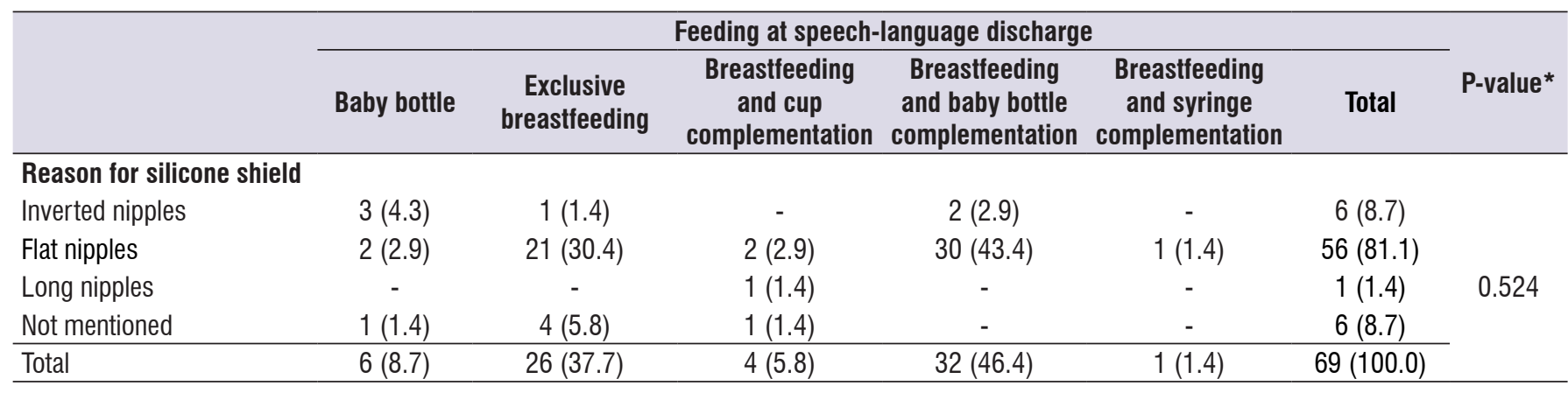

* Chi-squared test.

As shown in Table 5, the empty breast technique was performed by $20(7.7 \%)$ of the mothers, and all of them were discharged in exclusive breastfeeding. Of the $43(16.6 \%)$ that were submitted to the relactation/ translactation technique, 35 (13.5\%) were discharged in exclusive breastfeeding.

Table 5. Breastfeeding at the moment of speech-language discharge between mothers who were submitted to relactation/translactation and those submitted to empty breast techniques

\begin{tabular}{ccccc}
\hline & \multicolumn{3}{c}{ Breastfeeding $^{*}$} & \multirow{2}{*}{ p-value $^{* *}$} \\
\cline { 2 - 3 } Empty breast & Yes & No & Total & \\
Yes & $20(7.7 \%)$ & - & $20(7.7 \%)$ & \multirow{2}{*}{0.044} \\
No & $203(78.4 \%)$ & $36(13.9 \%)$ & $239(92.3 \%)$ & \\
Total & $223(86.1 \%)$ & $36(13.9 \%)$ & $259(100.0 \%)$ & \\
Relactation/Translactation & & & & \\
Yes & $35(13.5 \%)$ & $8(3.1 \%)$ & $43(16.6 \%)$ & 0.226 \\
No & $188(72.6 \%)$ & $28(10.8 \%)$ & $216(83.4 \%)$ & \\
Total & $223(86.1 \%)$ & $36(13.9 \%)$ & $259(100.0 \%)$ & \\
\hline
\end{tabular}

Legend: *Breastfeeding = Exclusive breastfeeding; Breastfeeding associated with cup complementation; Breastfeeding associated with baby bottle complementation; Breastfeeding associated with syringe complementation. **Fisher's exact test performed.

\section{DISCUSSION}

The profile of the NBs in this study (prevalence of moderately and extremely preterm; male; Apgar superior or equal to seven at the first and fifth minute) confirms the national literature ${ }^{12,13}$. Prematurity and low birth weight, as well as long periods of hospital stay, and the use of mechanical ventilation and medications, constitute important risk factors for alterations in the infants' development, growth and health conditions. These complications can cause alterations in short-and long-term development ${ }^{14}$. Nonetheless, prematurity is not a synonym to impossibility regarding breastfeeding, even if, at a first moment, the early interruption of gestation causes a strong emotional and clinical impact on the mother and the baby ${ }^{15}$.

This study has shown greater index of breastfeeding among NBs who did not need intubation. According to the literature, although a great number of preterm newborns need ventilatory support during neonatal hospital stay ${ }^{16}$, the possible influence of the orotracheal 
tube (OTT) on the development of the structures and functions of the stomatognathic system is still a theme little explored ${ }^{17}$. Study on the influence of OTT use on oral skills of preterm children, conducted in southern Brazil, concluded that preterm NBs submitted to OTT take longer to achieve full oral feeding ${ }^{17}$. For the authors, these NBs' follow-up by qualified professionals is fundamental to reduce the negative effects on the baby's oral abilities, resulting from the use of OTT in prematurity.

The immaturity of the stomatognathic system presented by the PTNB impairs the sucking function, making oral feeding more difficult ${ }^{18}$. Due to the limitations in coordinating in the sucking, swallowing and breathing functions, the PTNB almost always need to use alternative feeding routes ${ }^{19}$. The high use of alternative feeding route at the moment of speech-language assessment observed in this study, especially the orogastric one, makes breastfeeding more difficult, as the tube positioned in the oral cavity keeps the NB from having lip closure on their mother's breast, decreasing intraoral pressure.

The removal of the tube and transition to oral feeding must be stimulated as soon as possible, as long periods of gavage use (three or more weeks) for the feeding of preterm infants can cause complications, such as oral stimulation hypersensibility, choking, biting, crying and increased incidence of gastroesophageal reflux. Moreover, the longer the gavage use, more the child will be deprived of the oral sensorimotor experiences, which are important for global development ${ }^{4}$.

In this context, the speech-language therapist contributes to breastfeeding, as they stimulate sucking on the empty breast, simultaneous with tube feeding, which is considered a nonnutritive sucking (NNS) technique. This practice can contribute to exclusive breastfeeding ${ }^{19}$.

Even though the empty breast technique has not been much used at the service researched in this study, it is a technique that aids in breastfeeding, encouraging mother-baby contact and stimulating the mother's production of milk.

The relactation/translactation technique, used in some cases in this study, aims at favoring the production of breast milk, or increasing its volume, so as to dismiss the offer of complements through utensils, in order for the babies to be discharged in exclusive breastfeeding. However, the use of this technique is not always possible, due to the time of hospital stay and the clinical history of the newborns ${ }^{20}$.
Since the kangaroo method was in its implementation stage while this study was being conducted, and most of the professionals had not yet been trained on it, there were little use of the empty breast and the relactation/translactation techniques at the service. Such situation tends to change as the application of the norms of the kangaroo method is put into effect. Nevertheless, it is known that the early speechlanguage intervention favors the safe transition from tube to oral feeding, diminishing the time of hospital stay and the risk of infection, and contributing to a decreased maternity hospital $\cos ^{21}$.

Breastfeeding still reaches low rates in PTNB, as not only its frequency, but also its duration is smaller in these newborns, when compared to the full-term ones $^{22}$. The unsuccessful breastfeeding may result from the difficulty in maintaining an efficient milk production by the mother, because of stress and the mother being set apart from the baby; from the immaturity of the oral reflexes; from the unfavorable neonatal clinical conditions which keeps them from sucking directly from the breast; from the prolonged hospital stay; and from the manner how feeding transition is conducted ${ }^{22}$.

The study has evidenced high percentage of NBs positioned by their mother's breast in the same week of the speech-language assessment; in many cases, on the same day. Therefore, the presence of the mother at the hospital environment is considered fundamental for breastfeeding to be stimulated as early as possible.

Even though the results of the study show an important number of NBs in exclusive breastfeeding, there was need of complementary oral feeding to be offered to many NBs. The lack of a milk bank linked to the hospital decreases the stimulation of breast milking ${ }^{23}$, with the possible consequence of the preterm babies' mothers decreasing their production of milk.

Most of the NBs who used silicone nipple shield by indication of a speech-language therapist were discharged in breastfeeding or, in some cases, with baby bottle complementation. The use of silicone nipple shield in neonate breastfeeding is little cited in the literature; thus, following up patients who used this utensil is necessary to verify whether breastfeeding was maintained or they were early weaned.

Prescribing diet complementation in cups, syringes and baby bottle is of the responsibility of the medical staff; as for the speech-language and nurse professionals, they are the ones who must aid the mother/ relative in offering the complement. In this study, the offering of baby bottle complementation was prevalent, 
disagreeing with what is recommended by the kangaroo method ${ }^{5}$.

The study also evidenced that, with the implementation of the kangaroo method, the NBs began to be placed earlier by their mother's breast, taking into account the clinical condition and the suckingswallowing-breathing coordination, as prescribed by the kangaroo method, regardless of the gestational age of 32 to 34 weeks or the NB's weight ${ }^{5}$. It is believed that the preterm infants' early experience by their mother's breast improve breastfeeding prognosis, favoring early removal of alternative feeding route and speechlanguage discharge, making exclusive oral feeding possible, as well as the NB's weight gain, without any complications.

\section{CONCLUSION}

Breastfeeding was the most prevalent feeding method among the NBs in this study. Nonetheless, exclusive breastfeeding did not reach all the NBs, which is what the literature recommends. The results show that speech-language stimulation of the newborns was adapted from the conventional model to that proposed by the kangaroo method, and was consistent with the guidelines of humanized care. Therefore, the conceptual changes proposed by the kangaroo method are compatible with speech-language intervention, as both aim at the quality of caregiving.

It is necessary that measures be promoted and implemented in the hospital environment for breastfeeding to be made easier, aiming at the discharge of preterm NBs in exclusive breastfeeding, the continuity of breastfeeding after discharge, and the improvement in this population's quality of life. In this context, implementing the kangaroo method may increase exclusive breastfeeding rates.

\section{REFERENCES}

1. Rocha MS, Delgado SE. Intervenção fonoaudiológica em recém-nascido pré-termo com gastrosquise. Rev. soc. bras. fonoaudiol. [Internet]. 2007 [citado 2019 fev. 06];12(1):55-62. Disponível em: http://dx.doi.org/10.1590/ S1516-80342007000100011.

2. Varandas CPM, Campos LG, Motta AR. Adesão ao tratamento fonoaudiológico segundo a visão de ortodontistas e odontopediatras. Rev. soc. bras. fonoaudiol. [Internet]. 2008 [citado 2019 fev. 06];13(3):233-9. Disponível em: http://dx.doi. org/10.1590/S1516-80342008000300006.

3. Pivante $\mathrm{CM}$, Medeiros AMC. Intervenções fonoaudiológicas no aleitamento materno junto às mães de paridade zero. Mundo saúde. [Internet]. 2006 [citado 2019 fev. 06]; 30(1):87-95. Disponível em: http://www.saocamilo-sp.br/pdf/mundo_ saude/34/intervencoes_fonoaudiologas.pdf.

4. Willumsen DK, Guastalla R. Características específicas da Anatomofisiologia do Sistema Estomatognático na Prematuridade. In: Carvalho MR, Gomes CF (orgs). Amamentação - bases científicas. 4a ed. Rio de Janeiro: Guanabara, 2017. p. $330-8$.

5. Brasil. Ministério da Saúde, Secretaria de Atenção à Saúde, Departamento de Ações Programáticas Estratégicas. Atenção humanizada ao recémnascido de baixo peso: Método Canguru. 2. ed. Brasília: Ministério da Saúde, 2011. [citado 2019 fev. 06]. Disponível em: http://bvsms.saude.gov. br/bvs/publicacoes/atencao_humanizada_recem_ nascido_canguru.pdf.

6. Medeiros AMC, Sá TPL, Alvelos CL, Novais DSF. Speech therapy in food transition from probe to breast in newborn in kangaroo method. Audiol., Commun. Res. [Internet]. 2014 [cited 2019 Feb 06];19(1):95-103. Available from: http://www.scielo. br/pdf/acr/v19n1/en_2317-6431-acr-19-1-0095.pdf.

7. Magalhães $M$, Rodrigues FPM. Gallacci $C B$, Pachi R, Chopardi MR, Barbosa Neto T. Guia de bolso na neonatologia volume 1. 2. ed. Rio de Janeiro: Atheneu, 2016.

8. Brasil, Ministério da Saúde. Portaria n. 930, de 10 de maio de 2012. [Internet]. Brasília, 2012. [citado 2019 fev. 06] Disponível em: http:// bvsms.saude.gov.br/bvs/saudelegis/gm/2012/ prt0930_10_05_2012.html.

9. Deutsch AD, Dornaus MFPS, Waksman RD. O bebê prematuro: tudo o que os pais precisam saber. Barueri: Manole; 2013.

10. Watson J, McGuire W. Responsive versus scheduled feeding for preterm infants. Cochrane Database Syst Rev. [Internet]. 2016 [cited 2019 Feb 06];8:CD005255. Available from: http://dx.doi. org/10.1002/14651858.CD005255.pub5.

11. Mekonnen AG, Yehualashet SS, Bayleyegn AD. The effects of kangaroo mother care on the time to breastfeeding initiation among preterm and LBW infants: a meta-analysis of published studies. International Breastfeeding Journal. [Internet]: 2019 
[cited 2019 Sep 25]; 14:12. Available from: https:// doi.org/10.1186/s13006-019-0206-0.

12. Souza KCL, Campos NG, Santos Junior FFU. Profile of newborns undergoing early stimulation in a neonatal intensive care unit. Rev Bras PromocSaude. [Internet]. 2013 [cited 2019 Feb 06];26(4):519-24. Available from: http://dx.doi. org/10.5020/18061230.2013.p523.

13. Ermel AC, Grave MTQ. O índice de apgar em bebês recém-nascidos em um hospital de pequeno porte de um município do Vale do Paranhana. Revista Destaques Acadêmicos. [Internet]. 2011 [citado 2019 fev. 06];3(3):7-12. Disponível em: http://www. univates.br/revistas/index.php/destaques/article/ view/107.

14. Lemos RA, Frônio JS, Neves LAT, Ribeiro LC. Estudo da prevalência de morbidades e complicações neonatais segundo $o$ peso ao nascimento e a idade gestacional em lactentes de um serviço de follow-up. Rev. APS. [Internet]. 2010 [citado 2019 fev. 06];13(3):277-90. Disponível em: http://ojs2.ufjf.emnuvens.com.br/aps/article/ view/14411/7779.

15. Hitos SF, Periotto MC. Amamentação: atuação fonoaudiólogica - uma abordagem prática e atual. São Paulo: Revinter; 2009.

16. Naughton KA. The combined use of sucrose and nonnutritive sucking for procedural pain in both term and preterm neonates: an integrative review of the literature. Adv Neonatal Care. [Internet]. 2013 [cited 2019 Feb 06];13(1):9-19. Available from: http://dx.doi.org/10.1097/ANC.0b013e31827ed9d3.

17. Antunes VP, Berwig LC, Steidl SEM, Weinmann RM. Influence of the endotracheal tube on the feeding performance and signs of stress in preterm infants. Distúrb Comum. [Internet]. 2014 [cited 2019 Feb 06];26(3):569-75. Available from: https:// revistas. pucsp.br/index.php/dic/article/view/17416 Portuguese.

18. Silveira LM, Prade LS, Ruedell AM, Haeffner LSB, Weinmann ARM. Influence of breastfeeding on children's oral skills. Rev. Saúde Pública [Internet]. 2013 Feb [cited 2019 Feb 07]; 47(1):37-43. Available from: http://dx.doi.org/10.1590/ S0034-89102013000100006.

19. Medeiros AMC, Ramos BKB, Bomfim DLSS, Alvelos CL, Silva TC, Barreto IDC et al. Intervention time until discharge for newborns on transition from gavage to exclusive oral feeding. CoDAS. [Internet]. 2018 [cited 2019 Feb 07]; 30(2):e20170092. Availablefrom:http://dx.doi. org/10.1590/2317-1782/20182017092.

20. Mariano GJS. Relactação: identificação de práticas bem-sucedidas. Rev. Enf. Ref. [Internet]. 2011 [citado 2018 jun. 03]; serlll(3):163-70. Disponível em: http://www.scielo.mec.pt/ scielo.php? script $=$ sci_arttext $\&$ pid $=$ S087402832011000100017\&lng=pt.

21. Brock R. Recém-nascido prematuro, baixo de crescimento intra-uterino. In: Bassetto MCA, Brock $\mathrm{R}$, Wajnsztejn R (orgs). Neonatologia: um convite à atuação fonoaudiológica. São Paulo: Lovise; 1998. p. 67-73.

22. Scochi CGS, Ferreira FY, Góes FSN, Fujinaga $\mathrm{Cl}$, Ferecini GM, Leite AM. Alimentação láctea e prevalência do aleitamento materno em prematuros durante a internação em um hospital amigo da criança de Ribeirão Preto-SP, Brasil. Ciênc Cuid Saúde. [Internet]. 2008 [citado 2019 fev. 07]; 7(2):145-54. Disponível em:http://dx.doi. org/10.4025/cienccuidsaude.v7i2.4992.

23. Rocha ATS, Lira AYA, Malta DGB, Leitão LP, Mendes CKTT. A importância dos bancos de leite humano na garantia do aleitamento materno. Rev. Ciênc. Saúde Nova Esperança. [Internet]. 2016 [citado 2019 fev. 07]; 14(2):1-8. Disponível em: http:// www.facene.com.br/wp-content/uploads/2010/11/ Todos-os-arquivos-09-novembro-2016-1.pdf. 